\title{
Seasonal variability of the essential oil of Hesperozygis ringens (Benth.) Epling.
}

\author{
C. G. Pinheiro ${ }^{a}$, C. M. Machado ${ }^{b}$ L. P. Amaral ${ }^{a}$, D. T. Silva ${ }^{a}$, C. A. A. Almeida , \\ S. J. Longhi ${ }^{a}$, C. A. Mallmann ${ }^{c}$ and B. M. Heinzmann ${ }^{a, d *}$
}

\begin{abstract}
aPrograma de Pós-graduação em Engenharia Florestal, Centro de Ciências Rurais - CCR, Universidade Federal de Santa Maria - UFSM, Prédio 44, Campus Universitário, Avenida Roraima, 1000, Bairro Camobi, CEP 97105-900, Santa Maria, RS, Brazil

${ }^{b}$ Centro de Ciências Rurais - CCR, Universidade Federal de Santa Maria - UFSM, Prédio 42, Campus Universitário, Avenida Roraima, 1000, Bairro Camobi, CEP 97105-900, Santa Maria, RS, Brazil 'Laboratório de Análises Micotoxicológicas, Departamento de Medicina Veterinária Preventiva, Centro de Ciências Rurais - CCR, Universidade Federal de Santa Maria - UFSM, Prédio 44, Campus Universitário, Avenida Roraima, 1000, Bairro Camobi, CEP 97105-900, Santa Maria, RS, Brazil

dDepartamento de Farmácia Industrial, Centro de Ciências da Saúde, Universidade Federal de Santa Maria - UFSM, Prédio 26, Campus Universitário, Avenida Roraima, 1000, Bairro Camobi, CEP 97105-900, Santa Maria, RS, Brazil *e-mail: berta.heinzmann@gmail.com
\end{abstract}

Received: August 12, 2014 - Accepted: November 21, 2014 - Distributed: February 29, 2016

(With 2 figures)

\begin{abstract}
This study was developed to evaluate the effect of seasonality on the yield and chemical composition of the essential oil (EO) of Hesperozygis ringens (Benth.) Epling, a native species from the Brazilian Pampa. Leaves were collected from four specimens of a single population in each of the four seasons for a year and were extracted in triplicate by hydro-distillation for 2 hours. The yield of EO (\% w/w) was calculated on fresh weight basis (FWB), and the 16 oil samples were analyzed by gas chromatography coupled to mass spectrometry (GC-MS) and gas chromatography with flame ionization detector (GC-FID). Hierarchical Cluster Analysis (HCA) and Principal Component Analysis (PCA) were used as statistical tools to evaluate differences in chemical composition. The highest yields were obtained in autumn, spring and summer (2.32-4.38\%), while the lowest yields were detected in winter, ranging from 1.15 to $1.91 \%$. Oxygenated monoterpenoids were the predominant class of chemical constituents in the EO obtained in all seasons, showing the highest contents in autumn and summer, and pulegone was identified as a major compound, whose contents varied between 54.13 and $81.17 \%$. The EO samples were divided into three chemical groups by HCA and PCA and were assigned to the same group, except for the three samples gathered in winter. The results showed a seasonal influence on the yield and chemical composition of the EO.
\end{abstract}

Keywords: Lamiaceae, “espanta-pulga”, pulegone, oxygenated monoterpenoids.

\section{Variabilidade sazonal do óleo essencial de Hesperozygis ringens (Benth.) Epling.}

\section{Resumo}

Este estudo foi desenvolvido a fim de avaliar o efeito da sazonalidade no rendimento e composição química do óleo essencial (OE) de Hesperozygis ringens (Benth.) Epling., uma espécie nativa do Pampa brasileiro. Folhas foram coletadas de quatro indivíduos de uma mesma população, em cada uma das quatro estações de um ano, e foram extraídas em triplicada por hidrodestilação durante 2 horas. $\mathrm{O}$ rendimento do $\mathrm{OE}(\% \mathrm{~m} / \mathrm{m})$ foi calculado considerando a base fresca $(\mathrm{BF})$ e as 16 amostras de óleo foram analisadas por cromatografia gasosa acoplada à espectrometria de massas (CG-EM) e cromatografia gasosa com detector de ionização de chamas (CG-DIC). Análise Hierárquica de Cluster (AHC) e Análise de Componentes Principais (ACP) foram utilizadas como ferramentas estatísticas para avaliar as diferenças na composição química. Os maiores rendimentos foram obtidos no outono, primavera e verão (2,32-4,38\%), enquanto que os menores foram detectados no inverno, variando de 1,15 até $1,91 \%$. Os monoterpenoides oxigenados foram a classe predominante dos constituintes do OE obtido em todas as estações, apresentando os maiores teores no outono e no verão, e a pulegona foi identificada como o constituinte majoritário, cujos teores variaram entre 54,13 e 81,17\%. As amostras de OE foram divididas em três grupos químicos por AHC e ACP e foram classificadas no mesmo grupo, com exceção de três amostras coletadas no inverno. Os resultados demonstraram influência sazonal no rendimento e na composição química dos OE.

Palavras-chave: Lamiaceae, “espanta-pulga”, pulegona, monoterpenoides oxigenados. 


\section{Introduction}

The Brazilian Pampa is located in the state of Rio Grande do Sul, southern Brazil, between $28^{\circ} 00^{\prime} \mathrm{S}$ and $34^{\circ} 00^{\prime} \mathrm{S}$, and $49^{\circ} 30^{\prime} \mathrm{W}$ and $58^{\circ} 00^{\prime} \mathrm{W}$. This biome contains subtropical and temperate climates, has four welldefined seasons and is characterized by the presence of grassland with scattered trees and shrubs as the dominant vegetation types. Furthermore, the soil is fragile due to its sandy texture as a result of its sedimentary rock origin; in combination with the often harsh climatic conditions, this fragility has led to severe soil degradation, which compromises human activity and contributes to the low social development index presented by this region (IBGE, 2014; Roesch et al., 2009).

Currently, research pertaining to natural resources has grown in importance and is the basis for the development of sustainable uses of biodiversity, aiming to provide new opportunities and alternative sources of income for the local population. Moreover, the restoration of degraded soils by native plant species is considered strategic for their conservation. Essential oils (EO) are a natural resource often produced by the native species of the south Brazilian grassland. Hesperozygis ringens (Benth.) Epling (Lamiaceae) is a woody herb, 20 to $50 \mathrm{~cm}$ high, native to rocky fields of the Pampa biome with a very branched stem (Fracaro and Echeverrigaray, 2006; Von Poser et al., 1996). Some studies have described a high production of essential oil by its leaves, with pulegone as major component (Ribeiro et al., 2010; Silva et al., 2014; Toni et al., 2014; Von Poser et al., 1996). This species is known by the vernacular name "espanta-pulga" (literally “to keep fleas away") (Von Poser et al., 1996) and is used because of its anti-parasitic properties. The acaricidal, allelopathic, anesthetic and larvicidal activities of its EO have been already reported in the literature (Ribeiro et al., 2010; Silva et al., 2013, 2014; Von Poser et al., 1996).

Considering the above-described characteristics of the species, the goal of this study was to compare the yield and chemical composition of the EO obtained from fresh leaves of four individuals of $H$. ringens belonging to a single population in four different seasons (autumn, winter, spring and summer) of a year. Trying to detect possible seasonal and intrapopulation variability, the data were analyzed using the hierarchical cluster analysis (HCA) and principal component analysis (PCA) statistical tools.

\section{Material and Methods}

\subsection{Plant material}

Plant material was collected in São Francisco de Assis (S 29 35' 43, 1'; W 055 07' 33, 4'), Rio Grande do Sul, Brazil, between April 2012 and January 2013. Four specimens of $H$. ringens were chosen in the native growth area, and some of their leaves were collected in each season (autumn, winter, spring and summer). All collections of plant material occurred in the afternoon. Voucher specimen of $H$. ringens identified by Dr. Solon Jonas Longhi was deposited at the Herbarium of the Biology Department, UFSM, Brazil (SMDB 13.427).

\subsection{Essential oil extraction}

The essential oil was obtained from the fresh leaves of $H$. ringens by hydrodistillation using a Clevenger-type apparatus for 2 hours (Koc et al., 2013), and separated from water by decantation.

Plant material from each specimen was extracted in triplicate and the amount used in each extraction varied between 17 and $61 \mathrm{~g}$. The EO was then transferred to a graduated cylinder and weighed, followed by yield determination as $\% \mathrm{w} / \mathrm{w}$ on fresh weight basis (FWB). Samples were transferred to amber glass bottles and stored at $-4{ }^{\circ} \mathrm{C}$ until the chemical analysis.

\subsection{Chromatographic analysis}

The identification of the chemical components of the EO (qualitative analysis) was performed by an Agilent 6890 gas chromatograph coupled to an Agilent 5973 mass selective detector (GC/MS). The aliquot of $2 \mu \mathrm{L}$ of EO was diluted in $1 \mathrm{~mL}$ of hexane (grade HPLC). The analysis was carried out on a HP5-MS capillary column (Hewlett Packard, $5 \%$ phenyl, $95 \%$ methylsiloxane, $30 \mathrm{~m} \times 0.25 \mathrm{~mm}$, film thickness: $0.25 \mu \mathrm{m}$ ) at $70 \mathrm{eV}$. The following conditions were used: split inlet 1:100; temperature program: $40{ }^{\circ} \mathrm{C}$ for $4 \mathrm{~min} ; 40$ to $320^{\circ} \mathrm{C}$ at $4{ }^{\circ} \mathrm{C} \mathrm{min}^{-1}$; He as a gas carrier; flow rate $1 \mathrm{~mL} \mathrm{~min}^{-1}$; injector and detector temperatures: $250^{\circ} \mathrm{C}$. The EO components were identified by comparison of their retention indices, determined by a calibration curve of n-alkanes injected under the same chromatographic conditions as the samples and mass fragmentation patterns described in the literature (Adams, 2009; NIST, 2010).

The components of the EO were quantified by gas chromatography with flame ionization detection (GC/FID) on an Agilent 7890A in triplicate. The parameters used for the analyses were: splitless mode; temperature program: $40^{\circ} \mathrm{C}$ for $4 \mathrm{~min}$; 40 to $320^{\circ} \mathrm{C}$ at $4^{\circ} \mathrm{C} \mathrm{min}^{-1}$; He as gas carrier; flow rate $1 \mathrm{~mL} \mathrm{~min}{ }^{-1}$; injector and detector temperatures: $300{ }^{\circ} \mathrm{C}$. The percentage of the chemical components was based on peak area normalization.

\subsection{Statistical analysis}

The yields of the EO were evaluated by descriptive statistics, performed in a spreadsheet (Excel®). For the analysis of the yields, a bifactorial design $(4 \times 4)$ was used: Factor 1 - seasons (autumn, winter, spring and summer), and Factor 2 - specimens (1, 2, 3 and 4), providing 16 treatments with 3 replications each, totaling 48 observations. The yield results were submitted to Kolmogorov-Smirnov and Bartlett tests to check the normality and homogeneity of variances, respectively. The differences in yields were evaluated by two-way ANOVA to verify the effects of seasonality and individuality on this variable. The Tukey test was applied aiming to compare mean values. Data regarding the amounts of limonene, linalool, isopulegol, isopulegone, verbenone, pulegone, $\beta$-caryophyllene, germacrene $\mathrm{D}$, and elixene, as well as the identified chemical classes were submitted to Friedman test using Assistat version 7.6 Beta.

For the definition of chemical groups using the EO composition, hierarchical cluster analysis (HCA) and principal 
component analysis (PCA) were performed, examining the relative percentages of the 25 major constituents $(\geq 1 \%$ ). For HCA, Euclidean distance was used as a dissimilarity measure, while a horizontal dendrogram was obtained by the Single Linkage method. Based on the distances between samples, the Single Linkage was chosen as an amalgamation rule. The PCA was used to determine the variables (constituents) that influenced the formation of groups (Mardia et al., 1994). For purposes of analysis, each sample of EO was considered a "case" and each constituent a "descriptor variable". Analyses were performed using the software Statistica 6.0.

\section{Results}

GC-MS and GC-FID analysis allowed the identification of 37 compounds in the 16 EO samples, which were classified into six different chemical classes (see Table 1).

Table 1. Averages (\%) of the identified chemical constituents, major chemical classes, and yields of the essential oils from leaves of four specimens of Hesperozygis ringens collected in four different seasons.

\begin{tabular}{|c|c|c|c|c|c|c|c|}
\hline Compound & Min RI ${ }^{a}$ & Máx RI ${ }^{\mathbf{b}}$ & RI Lit ${ }^{c, d}$ & Autumn & Winter & Spring & Summer \\
\hline$\alpha$-Pinene & 930.75 & 932.34 & 930.00 & 0.36 & 0.77 & 0.44 & 0.51 \\
\hline Camphene & 946.01 & 947.43 & 953.00 & 0.17 & 0.20 & 0.16 & 0.13 \\
\hline Sabinene & 970.30 & 972.06 & 970.00 & 0.19 & 0.22 & 0.29 & 0.24 \\
\hline$\beta$-Pinene & 972.81 & 974.73 & 968.00 & 0.35 & 0.72 & 0.36 & 0.48 \\
\hline 1-Octen-3-ol & 974.54 & 977.54 & 976.00 & 0.90 & - & - & 0.05 \\
\hline$\beta$-Myrcene & 988.17 & 989.87 & 988.00 & 0.25 & 0.89 & 0.42 & 0.58 \\
\hline Limonene & 1025.64 & 1030 & 1026.00 & $1.65 \mathrm{a}$ & $2.86 \mathrm{a}$ & $2.37 \mathrm{a}$ & $2.81 \mathrm{a}$ \\
\hline$\beta$-E-ocimene & 1047.80 & 1047.80 & 1035.00 & 0.19 & - & - & - \\
\hline$\beta$-Z-ocimene & 1046.76 & 1051.04 & 1047.00 & 1.02 & 0.36 & 0.71 & 0.71 \\
\hline Eucalyptol & 1028.25 & 1031.06 & 1037.00 & 0.25 & 0.71 & - & 0.19 \\
\hline Linalool & 1097.50 & 1111.89 & 1106 & $1.42 \mathrm{a}$ & $2.05 \mathrm{a}$ & $1.64 \mathrm{a}$ & $1.31 \mathrm{a}$ \\
\hline $\begin{array}{l}\text { Octen-1-ol } \\
\text { acetate }\end{array}$ & 1099.63 & 1199.87 & 1100.00 & 0.05 & - & - & - \\
\hline $\begin{array}{l}p \text {-Mentha-1.3.8- } \\
\text { triene }\end{array}$ & 1116.47 & 1117.50 & 1113.00 & 0.13 & - & 0.14 & 0.18 \\
\hline $\begin{array}{l}\text { Octen-3-yl } \\
\text { acetate }<1->\end{array}$ & 1112.57 & 1117.38 & 1113.00 & - & 0.39 & - & - \\
\hline$p$-Menthone & 1129.41 & 1129.41 & 1129.00 & - & 0.03 & - & - \\
\hline Isopulegol & 1163.03 & 1165.78 & 1156.00 & $0.97 \mathrm{a}$ & $2.76 \mathrm{a}$ & $1.65 \mathrm{a}$ & $1.59 \mathrm{a}$ \\
\hline Isomenthone & 1165.57 & 1165.57 & 1165.00 & 0.21 & - & - & - \\
\hline Isopulegone & 1175.44 & 1178.11 & 1177.00 & $1.52 \mathrm{a}$ & $4.83 \mathrm{a}$ & $1.58 \mathrm{a}$ & $2.24 \mathrm{a}$ \\
\hline$\alpha$-Terpineol & 1191.75 & 1201.31 & 1197.00 & 0.33 & 0.53 & 0.33 & 0.15 \\
\hline Verbenone & 1210.25 & 1215.61 & 1205.00 & $0.33 b$ & $3.07 \mathrm{a}$ & $0.36 \mathrm{~b}$ & $0.77 \mathrm{~b}$ \\
\hline $\begin{array}{l}\text { 2.6-Dimethyl- } \\
\text { 3.5.7-octatriene- } \\
\text { 2-ol. .E.E- }\end{array}$ & 1216.19 & 1216.19 & 1209.20 & - & 0.19 & - & - \\
\hline Pulegone & 1248.49 & 1254.00 & 1244.00 & $81.17 \mathrm{a}$ & $53.93 \mathrm{c}$ & $76.91 \mathrm{~b}$ & $79.02 \mathrm{ab}$ \\
\hline$\delta$-Elemene & 1339.37 & 1344.26 & 1344.00 & 0.23 & 0.36 & 0.20 & 0.23 \\
\hline Eucarvone & 1343.69 & 1350.47 & 1343.00 & 0.18 & 0.74 & 0.28 & 0.17 \\
\hline $\begin{array}{l}\alpha \text {-Terpineol } \\
\text { acetate }\end{array}$ & 1349.13 & 1355.22 & 1351.00 & 0.26 & 0.21 & 0.28 & 0.15 \\
\hline $\begin{array}{l}\text { Phenyl ethyl } \\
\text { isobutanoate }\end{array}$ & 1386.19 & 1395.46 & 1394.00 & 0.15 & 0.15 & 0.13 & 0.10 \\
\hline$\beta$-Caryophyllene & 1419.41 & 1424.88 & 1418.30 & $0.94 \mathrm{a}$ & $1.10 \mathrm{a}$ & $0.95 \mathrm{a}$ & $1.21 \mathrm{a}$ \\
\hline$\alpha$-Caryophyllene & 1428.14 & 1430.49 & 1438.00 & 0.16 & 0.15 & 0.17 & 0.10 \\
\hline Aromadendrene & 1432.28 & 1432.28 & 1440.00 & - & 0.08 & - & - \\
\hline Germacrene D & 1480.81 & 1498.18 & 1489.00 & $0.15 c$ & $3.34 \mathrm{a}$ & $0.40 \mathrm{~b}$ & $0.22 b c$ \\
\hline
\end{tabular}

${ }^{\mathrm{a}}$ Min RI= Minimum retention index value. ${ }^{\mathrm{b}} \mathrm{Max} \mathrm{RI}=$ Maximum retention index value. References: ${ }^{\mathrm{c}}$ Adams (2009). ${ }^{\mathrm{d}} \mathrm{NIST}(2010)$. Data are expressed as mean values ( $n=3$ for the yields and $n=4$ for chemical constituents and chemical classes). For yields, different capital letters in the same columns indicate significant differences between the different specimens in the same season, and different lowercase letters in the rows indicate significant differences for the same specimen in distinct seasons. Tukey test $(P<0.05)$. For the main constituents and chemical classes, different lowercase letters in the same row indicate significant difference between the seasons. Friedman test $(P<0.05)$. 
Table 1. Continued...

\begin{tabular}{|c|c|c|c|c|c|c|c|}
\hline Compound & Min RI $^{a}$ & Máx RI ${ }^{b}$ & RI Lit ${ }^{c, d}$ & Autumn & Winter & Spring & Summer \\
\hline Elixene & 1495.17 & 1500.11 & 1492.00 & $0.28 \mathrm{a}$ & $8.62 \mathrm{a}$ & $0.31 \mathrm{a}$ & $0.36 \mathrm{a}$ \\
\hline Bicyclogermacrene & 1498.89 & 1499.97 & 1500.00 & 0.29 & - & - & 0.12 \\
\hline Ledol & 1583.87 & 1583.87 & 1588.00 & - & 0.32 & - & - \\
\hline Spathulenol & 1573.8 & 1587.16 & 1578 & 0.35 & 0.54 & 0.67 & 0.49 \\
\hline $\begin{array}{l}\text { Caryophyllene } \\
\text { oxide }\end{array}$ & 1580.92 & 1590.05 & 1581.00 & 0.30 & 0.76 & 0.10 & 0.36 \\
\hline Viridiflorol & 1589.31 & 1598.42 & 1590.00 & 0.27 & 0.25 & 0.70 & - \\
\hline $\begin{array}{l}\text { Aromadendrene } \\
\text { epoxide }<\text { allo- }>\end{array}$ & 1637.37 & 1643.93 & 1541.00 & 0.10 & 0.39 & 0.43 & 0.29 \\
\hline Identified Compo & Inds & & & 93.41 & 92.49 & 92.09 & 94.88 \\
\hline Monoterpene Hy & rocarbons & & & $4.6 \mathrm{a}$ & $7.48 \mathrm{a}$ & $4.9 \mathrm{a}$ & $5.86 a$ \\
\hline Hydroxylated Hy & Irocarbons & & & $0.08 \mathrm{a}$ & $0.09 \mathrm{a}$ & $0 \mathrm{a}$ & $0.16 \mathrm{a}$ \\
\hline Oxygenated Mon & terpenoids & & & $86.2 \mathrm{a}$ & $68.51 \mathrm{c}$ & $82.77 b$ & $85.27 \mathrm{a}$ \\
\hline Sesquiterpene $\mathbf{H y}$ & drocarbons & & & $2.35 \mathrm{a}$ & $13.88 \mathrm{a}$ & $2.33 \mathrm{a}$ & $2.37 \mathrm{a}$ \\
\hline Phenylpropanoid & & & & $0.15 \mathrm{a}$ & $0.15 \mathrm{a}$ & $0.13 a$ & $0.06 \mathrm{a}$ \\
\hline Oxygenated Sesq & iiterpenoids & & & $1.01 \mathrm{a}$ & $2.09 \mathrm{a}$ & $1.91 \mathrm{a}$ & $1.27 \mathrm{a}$ \\
\hline \multirow{2}{*}{ Specimen } & \multicolumn{7}{|c|}{ Essential Oil Yield per Season } \\
\hline & \multicolumn{2}{|c|}{ Autumn } & \multicolumn{2}{|c|}{ Winter } & Spring & \multicolumn{2}{|r|}{ Summer } \\
\hline 1 & \multicolumn{2}{|c|}{$3.46 \mathrm{aA}$} & \multicolumn{2}{|c|}{$1.45 \mathrm{cB}$} & $2.32 \mathrm{bD}$ & \multicolumn{2}{|r|}{$3.31 \mathrm{aA}$} \\
\hline 2 & \multicolumn{2}{|c|}{$3.07 \mathrm{aAB}$} & \multicolumn{2}{|c|}{$1.43 \mathrm{bB}$} & $2.83 \mathrm{aC}$ & \multicolumn{2}{|r|}{$2.64 \mathrm{aB}$} \\
\hline 3 & \multicolumn{2}{|c|}{$3.01 \mathrm{bB}$} & \multicolumn{2}{|c|}{$1.15 \mathrm{cB}$} & $3.59 \mathrm{aB}$ & \multicolumn{2}{|r|}{$3.33 \mathrm{abA}$} \\
\hline 4 & \multicolumn{2}{|c|}{$3.48 \mathrm{bA}$} & \multicolumn{2}{|c|}{$1.91 \mathrm{cA}$} & $4.38 \mathrm{aA}$ & \multicolumn{2}{|r|}{$3.17 \mathrm{bA}$} \\
\hline
\end{tabular}

${ }^{\mathrm{a}}$ Min RI= Minimum retention index value. ${ }^{\mathrm{b}} \mathrm{Max} \mathrm{RI}=$ Maximum retention index value. References: ${ }^{\mathrm{c} A d a m s}$ (2009). ${ }^{\mathrm{d}}$ NIST (2010). Data are expressed as mean values ( $n=3$ for the yields and $n=4$ for chemical constituents and chemical classes). For yields, different capital letters in the same columns indicate significant differences between the different specimens in the same season, and different lowercase letters in the rows indicate significant differences for the same specimen in distinct seasons. Tukey test $(P<0.05)$. For the main constituents and chemical classes, different lowercase letters in the same row indicate significant difference between the seasons. Friedman test $(P<0.05)$.

The percentages of some constituents, such as limonene, linalool, isopulegol, isopulegone, $\beta$-caryophyllene, and elixene, suffered no significant interference from the season. However, autumn and summer provided higher contents of pulegone and, although in winter its content decreased, other constituents such as verbenone and germacrene D presented higher values in this season. On average, autumn and summer showed higher contents of oxygenated monoterpenoids (OM), which were the major constituents in all seasons (see Table 1). A significant decrease in the relative amount of OM could be observed in winter. This season also showed an increase of the content of sesquiterpene hydrocarbons; however, without significant differences when compared to the other seasons (see Table 1).

In addition to OM, the second class of constituents most frequently found was the monoterpene hydrocarbons. Furthermore, the oxygenated sesquiterpenoids were detected in small percentages, between 1 and $2 \%$, in all seasons. Finely, the hydroxylated hydrocarbons and phenylpropanoids occurred as trace components, with percentages smaller than $1 \%$ (see Table 1 ).

The descriptive statistics of yields indicated the minimum and maximum values of 1.13 and $4.43 \%$, respectively, while the coefficient of variation $(\mathrm{CV})$, standard error (SE) and standard deviation (S) found for this variable was $31.89 \%$, 0.16 and 0.89 , respectively. Comparison of the average yields for the different specimens in all collection seasons (see Table 1) shows that, in general, specimen 4 showed more potential for EO production. However, autumn, spring and summer seem to have produced better EO yields in comparison to winter, which generated smaller amounts of EO.

The PCA showed 15 principal components (PC), with the first representing $40.81 \%$ of the total variance, including pulegone. The second $\mathrm{PC}$ contributed with $19.56 \%$ of the total variance and is represented by $\beta$-myrcene, $\alpha$-terpineol, ledol and caryophyllene oxide. PC 3, 4 and 5 provided $13.27,7.31$ and $4.81 \%$ of the total variance and are represented by non-identified component 2 (NI2), spathulenol and NI6, respectively. The first five PC had eigenvalues greater than 1 and explained $85.76 \%$ of the total variance (see Figure 1).

The sesquiterpenoids caryophyllene (c18), viridiflorol (c24) and spathulenol (c22), together with the non-identified compounds NI6 (c25) and NI5 (c17), provided a small contribution to PC 1 and 2 (see Figure 1). The comparison of Figures 1a and $1 \mathrm{~b}$ shows that the compounds NI3 (c15), NI4 (c16), ledol (c21) and caryophyllene oxide (c23) are related to the second winter sample (WIN2), while 

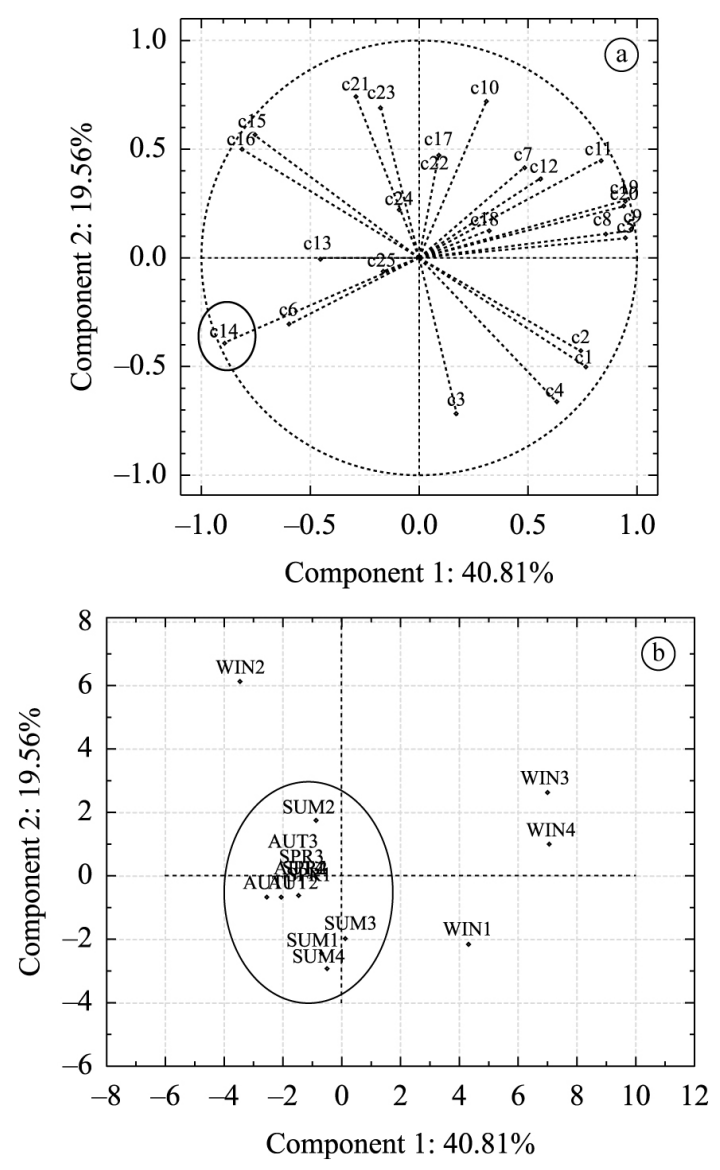

Figure 1. Representation of the variables (a) and samples (b) on the plans of principal components 1 and 2, considering the 25 major constituents of the 16 essential oil samples obtained from the fresh leaves of Hesperozygis ringens in different seasons. The ellipses highlight pulegone (c14) and the samples from autumn (AUT 1-4), spring (SPR 1-4) and summer (SUM 1-4). Legend: $\mathrm{c} 1=\alpha$-Pinene; $\mathrm{c} 2=\beta$-Pinene; $\mathrm{c} 3=\beta$-Myrcene; $\mathrm{c} 4=$ Limonene; $\mathrm{c} 5=$ Eucalyptol; $\mathrm{c} 6=\beta$-E-ocimene; c7 = Linalool; $\mathrm{c} 8=$ Isopulegol; $\mathrm{c} 9=$ Isopulegone; $\mathrm{c} 10=\alpha$-Terpineol; $\mathrm{c} 11=$ Verbenone; $\mathrm{c} 12=\mathrm{NI} 1 ;$ $\mathrm{c} 13=$ NI2; $14=$ Pulegone $\mathrm{c} 15=$ NI3; c16 = NI4; c17 = NI5; $\mathrm{c} 18=$ Caryophyllene; $\mathrm{c} 19=$ Germacrene D; c20 = Elixene; c21 = Ledol; c22 = Spathulenol; c23 = Caryophyllene oxide; c24 = Viridiflorol; c25 = NI6. AUT 1-4, WIN 1-4, SPR 1-4 and SUM 1-4= Samples of EO obtained in autumn, winter, spring and summer, respectively.

pulegone (c14) has a smaller correlation with the winter samples (WIN1, WIN2, WIN3 and WIN4) than with the other seasons samples.

The hierarchical cluster analysis (HCA) promoted the division of the samples into three chemical groups (A, B and C) (see Figure 2). Group A is represented by the samples obtained in autumn (AUT 1-4), spring (SPR 1-4), summer (SUM 1-4) and a single sample from winter (WIN 2). All of these samples exhibited concentrations of pulegone that ranged between 68.12 and $83.91 \%$. Group B consisted of

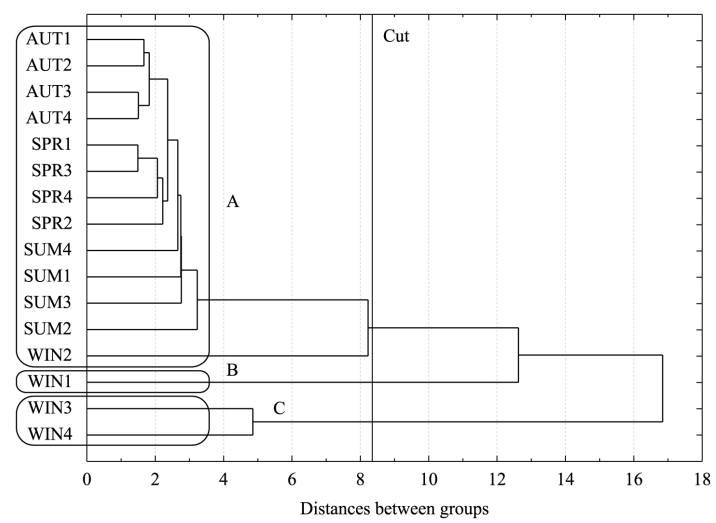

Figure 2. Dendrogram generated by HCA of the chemical composition of 16 samples of essential oils obtained from the leaves of Hesperozygis ringens, highlighting groups A, B and C. Legend: AUT 1-4, WIN 1-4, SPR 1-4 and SUM 1-4: Samples of EO obtained in autumn, winter, spring and summer, respectively.

only the first sample obtained in winter (WIN 1), while the last group (C) encompassed the two remaining samples of this season (WIN 3 and 4).

In WIN 2, the concentration of pulegone $(68.12 \%)$ was lower than in the samples from the other seasons but similar enough to be classified in group A. The WIN 1 showed a lower concentration of pulegone (59.37\%); therefore, the HCA formed a new group with this sample. In addition, the other winter samples, WIN 3 and WIN 4, presented similar concentrations of pulegone (45.89 and 43.14 , respectively) and were classified in the third group (see Figure 2). This analysis demonstrated the greater chemical variability on the EO samples obtained in winter.

Within Group A (see Figure 2), spring samples 1 and 3 showed more similarity, evidenced by their smaller Euclidean distance. A similar situation occurred with samples 3 and 4 obtained in autumn. In this season, samples 1 and 2 also presented a strong similarity but had a greater Euclidean distance than samples 3 and 4 . This distinction can be explained by the lower concentrations of pulegone in the first two samples (AUT 1 and AUT 2) compared with the other two (AUT 3 and AUT 4). Sample 2 obtained in summer (SUM 2) presented a greater Euclidean distance than the other three samples obtained in this season, which can be explained by its lower concentration of pulegone.

\section{Discussion}

Some studies have reported EO yields for the leaves of $H$. ringens considering both the fresh and dry weight bases (Fracaro, 2006; Ribeiro et al., 2010; Silva et al., 2013; Von Poser et al., 1996). In the present study, the yields were expressed in fresh weight basis because different authors have described EO loss in the leaves of Lamiaceae species and changes in the chemical composition of the oil due to drying processes (Argyropoulos and Müller, 2014; Sellami et al., 2012). During drying, the moisture moves 
by diffusion from the interior of the leaves to surface and can carry the EO with it, thus affecting the productivity (Argyropoulos and Müller, 2014). According to Venskutonis (1997), depending on the drying method, the biological structure of the oil gland trichomes of some Lamiaceae species can be strongly affected. One way to consider the yield on dry weight basis without the risk of losing EO is to extract the oil from fresh material and to determine the moisture content, as already described in the literature (Pimentel et al., 2012).

The EO yields obtained from $H$. ringens showed a dependence on seasonality, which has also been described in previous studies for other species of Lamiaceae (Gazim et al., 2010). Beyond the season and drying state of the plant material, the EO yield and composition can be affected by other factors, such as stage of plant development, light, temperature, soil, altitude, rainfall, liming and harvest time (Blank et al., 2005; Gobbo-Neto and Lopes, 2007; Lakušić et al., 2011; Lima et al., 2003; Mossi et al., 2012). Although the EO yield and chemical composition are influenced by a number of factors, literature shows that these parameters may be independent of factors such as aluminum concentration (Mossi et al., 2011). On the other hand, the production of secondary metabolites and the composition of complex mixtures such as EO can also be influenced by environmental conditions, such as pollution, climate, and diseases (Figueiredo et al., 2008).

Other studies regarding the EO from fresh leaves of $H$. ringens reported higher yields, of approximately $4.0 \%$, compared to the corresponding data found in this work (Ribeiro et al., 2010; Von Poser et al., 1996). Hesperozygis species are characterized by high yields of EO when the fresh material is extracted. The leaves of $H$. rhododon presented a yield of $1.0 \%$, whereas the aerial parts of H. marifolia had a yield of 2.0\% (Gonzáles-Chávez et al., 2011; Von Poser et al., 1996). In general, species classified in the Lamiaceae stand out by presenting high potential for EO production (Mechergui et al., 2010; Monfared and Ghorbanli, 2010; Ozcan et al., 2011; Raina et al., 2013; Saei-Dehkordi et al., 2010; Touati et al., 2011; Zouari et al., 2011).

Considering the analyzed seasons, autumn, spring and summer showed higher EO yields. Analyzing the seasonal influence in the EO production of the Lamiaceae species, summer usually stands out as the season that provides the highest $\mathrm{EO}$ content. This observation may indicate a positive influence of higher temperatures that, together with precipitation, can positively affect the vegetative growth (Botrel et al., 2010; Santos et al., 2012). Another factor to be considered is flowering. According to the field observations of this study, the flowering of $H$. ringens begins in spring, continues strongly in summer and remains in autumn. Thus, the EO yields found suggest that EO production may be related to the flowering period. Similar behavior has been described in other Lamiaceae species, which were found to present the maximum EO production at the peak of flowering (Botrel et al., 2010; Lakušić et al., 2011; Pérez-Sánchez et al., 2012). However, exceptions to this trend were also detected in Lamiaceae (Gazim et al., 2010); therefore, the yields of all species with the potential to produce essential oil should be assessed considering the phenological phases and the variables to which the plants are commonly subjected. In contrast, lower levels of essential oil in winter can be related to the greater number of rainy days in southern Brazil during the winter months (Silva et al., 2007), which can remove the EO from the leaves, causing losses because the structures for EO storage in Lamiaceae species are located on the surface (Sandes et al., 2012). In addition, the lower EO yields found in this season can be associated to the moisture content present in the leaves due to the high relative humidity. According to literature reports, Lamiaceae species can have EO production negatively affected by excess of water in months of high rainfall (Carneiro et al., 2010).

Analyzing the specimens reveals that their yields indicate low intrapopulation variability, which is not surprising. According to Fracaro and Echeverrigaray (2006), intrapopulation variability in $H$. ringens may exist, but it is lower than the interpopulation variability, suggesting limited gene flow between populations. Qualitative and quantitative chemical variations of the EO can be observed within and between populations, indicating a relationship with the geographic distribution and its importance for species survival in its natural habitat (Fracaro, 2006). The variations in the EO production between individuals of other Lamiaceae species among and within populations have been already described (Agostini et al., 2006; Lakušić et al., 2013; Lukas et al., 2013; Munõz-Bertomeu et al., 2007), and the geographic distribution has proven to be the primary determinant controlling its diversity within populations (Trindade et al., 2008) or among them (Agostini et al., 2006).

According to literature reports, the percentage of pulegone in the $\mathrm{EO}$ of $H$. ringens can range between 79.2-96.63\% (Silva et al., 2013; Von Poser et al., 1996). Some studies indicate biological effects of this constituent, such as allelopathic, acaricide and insecticide (Basbagci and Erler, 2013; Mucciarelli et al., 2001; Ribeiro et al., 2010). This OM can also be found in other Hesperozygis species, usually at lower concentrations, but it is frequently the major compound of the EO, as in H. marifolia (40.75\% of (R)-pulegone) (Gonzáles-Chávez et al., 2011) and H. myrtoides, (44.4\%) (Martini et al., 2011). In the case of $H$. rhododon, its major compound is menthone (43.4\%), a monoterpenoid derivative with similar structure, while pulegone also occurs at high percentages (29.6\%) (Von Poser et al., 1996).

Considering the variations of the contents of $\mathrm{OM}$ and pulegone between seasons, autumn and summer had a statistically similar deportment, yielding the highest contents. Seasonal variation in monoterpenoid contents has been reported previously in other Lamiaceae species (Botrel et al., 2010; Grausgruber-Groger et al., 2012; Santos et al., 2012), and the levels of (+)-pulegone have also been shown to be influenced by seasonality in Micromeria fruticosa, reaching maximal content during the summer (Dudai et al., 2001). In the present study, pulegone remained as major component during the four seasons. 
Terpenoids have already been reported in the literature as major constituents in the EO of other Lamiaceae species, such as patchoulol in Pogostemon cablin (Blanco) Benth. (Blank et al., 2011).

Studies regarding the chemical composition of the EO from different species of Lamiaceae indicate that they are composed mainly of monoterpenoids (Hussain et al., 2013; Koc et al., 2013; Moro et al., 2011; Touati et al., 2011; Yousefzadeh et al., 2013). This result is not surprising because the well-known biosynthetic processes of terpenoids in plants are genetically controlled, and species classified in the same family often present major compounds of the same class (Lukas et al., 2013; Najafian, 2014).

The analyses by PCA and HCA indicate a slight seasonal influence on the EO of $H$. ringens, with the oil obtained from leaves collected in winter showing the greatest differences compared to other seasons. Considering that different enzymes responsible for the formation of terpenoids are stimulated by ultraviolet-B and photosynthetically active radiation (Behn et al., 2010), the results of this work suggest that the conditions imposed on the species in winter, i.e. the shorter and overcast days characteristic of this season in southern Brazil, may have negatively influenced the yield of EO and its pulegone content. Beyond monoterpenoids, the seasonality can also influence the contents of sesquiterpenoids (Botrel et al., 2010; Freire et al., 2006; Gazim et al., 2010). The collection time of the plant material is an important factor because the amount, and sometimes the nature, of the active constituents are often not constant throughout the year (Gobbo-Neto and Lopes, 2007). Besides the changes in the constituent contents, the seasonality can still influence the biological activities of EO from Lamiaceae species (Hashemi et al., 2013).

Considering that autumn, spring and summer produced the highest yields of EO and at the same time provided high contents of OM and pulegone, this study indicates these seasons as the most appropriate to collect the leaves of $H$. ringens to obtain EO. Considering the high yields of EO and its chemical composition, almost exclusively constituted by pulegone, new studies should be conducted with $H$. ringens to search for ways to cultivate and reproduce the species. Comparing the individual yields, specimens 1, 3 and 4 would be indicated as mother plants to collect seeds or for in vitro propagation experiments aiming to produce seedlings.

\section{Acknowledgements}

This study was supported by Fundação de Amparo à Pesquisa do Estado do Rio Grande do Sul (FAPERGS/PRONEX, process 10/0016-8). Carlos Augusto Mallmann and Solon Jonas Longhi are grateful to Conselho Nacional de Pesquisa e Desenvolvimento Científico (CNPq) for their research fellowships; Carlos Garrido Pinheiro, Daniela Thomas da Silva and Lúcio de Paula Amaral are grateful to Coordenação de Aperfeiçoamento de Pessoal de Nível Superior (CAPES) for their graduate fellowships. Césare Mattioda Machado is grateful to $\mathrm{CNPq}$ for his undergraduate scholarship.

\section{References}

ADAMS, R.P., 2009. Identification of essential oil components by gas chromatography/quadrupole mass spectroscopy. Carol Stream: Allured Publishing Corporation.

AGOSTINI, G., AGOSTINI, F., ATTI-SERAFINI, L. and ECHEVERRIGARAY, S., 2006. Essential oil variability within and among populations of Cunila incisa Benth. Biochemical Systematics and Ecology, vol. 34, no. 11, pp. 802-808. http:// dx.doi.org/10.1016/j.bse.2006.04.007.

ARGYROPOULOS, D. and MÜLLER, J., 2014. Changes of essential oil content and composition during convective drying of lemon balm (Melissa officinalis L.). Industrial Crops and Products, vol. 52, pp. 118-124. http://dx.doi.org/10.1016/j. indcrop.2013.10.020.

BASBAGCI, G. and ERLER, F., 2013. Evaluation of some essential oils and their major components against mushroom scatopsid flies as fumigants. Fresenius Environmental Bulletin, vol. 22 , no. 11 , pp. 3170-3178.

BEHN, H., ALBERT, A., MARX, F., NOGA, G. and ULBRICH, A., 2010. Ultraviolet-B and photosynthetically active radiation interactively affect yield and pattern of monoterpenes in leaves of peppermint (Mentha piperita L.). Journal of Agricultural and Food Chemistry, vol. 58, no. 12, pp. 7361-7367. http://dx.doi. org/10.1021/jf9046072. PMid:20481601.

BLANK, A.F., FONTES, S.M., CARVALHO FILHO, J.L.S., ALVES, P.B., SILVA-MANN, R., MENDONÇA, M.C., ARRIGONIBLANK, M.F. and RODRIGUES, M.O., 2005. Influência do horário de colheita e secagem de folhas no óleo essencial de melissa (Melissa officinalis L.) cultivada em dois ambientes. Revista Brasileira de Plantas Medicinais, vol. 8, no. 1, pp. 73-78.

BLANK, A.F., SANT'ANA, T.C.P., SANTOS, P.S., ARRIGONIBLANK, M.F., PRATA, A.P.N., JESUS, H.C.R. and ALVES, P.B., 2011. Chemical characterization of the essential oil from patchouli accessions harvested over four seasons. Industrial Crops and Products, vol. 34, no. 1, pp. 831-837. http://dx.doi. org/10.1016/j.indcrop.2011.01.021.

BOTREL, P.P., PINTO, J.E.B.P., FERRAZ, V., BERTOLUCCI, S.K.V. and FIGUEIREDO, F.C., 2010. Teor e composição química do óleo essencial de Hyptis marrubioides Epl., Lamiaceae em função da sazonalidade. Acta Scientiarum: Agronomy, vol. 32, no. 3, pp. 533-538.

CARNEIRO, F.B., JÚNIOR, I.D., LOPES, P.Q. and MACÊDO, R.O., 2010. Variação da quantidade de $\beta$-cariofileno em óleo essencial de Plectranthus amboinicus (Lour.) Spreng., Lamiaceae, sob diferentes condições de cultivo. Revista Brasileira de Farmacognosia, vol. 40, no. 4, pp. 600-606. http://dx.doi. org/10.1590/S0102-695X2010000400021.

DUDAI, N., LARKOV, O., RAVID, U., PUTIEVISC, E. and LEWINSOHN, E., 2001. Developmental Control of Monoterpene Content and Composition in Micromeria fruticosa (L.) Druce. Annals of Botany, vol. 88, no. 3, pp. 349-354. http://dx.doi. org/10.1006/anbo.2001.1466.

FIGUEIREDO, A.C., BARROSO, J.G., PEDRO, L.G. and SCHEFFER, J.J.C., 2008. Factors affecting secondary metabolite production in plants: volatile components and essential oils. Flavour and Fragrance Journal, vol. 23, no. 4, pp. 213-226. http://dx.doi.org/10.1002/ffj.1875. 
FRACARO, F., 2006. Ecologia molecular, variabilidade genética, química e cultivo in vitro de Hesperozygis ringens Benth. São Carlos: Universidade Federal de São Carlos, 89 p. PhD Thesis.

FRACARO, F. and ECHEVERRIGARAY, S., 2006. Genetic variability in Hesperogyzis ringens Benth. (Lamiacea), an endangeder aromatic and medicinal plant of southern Brazil. Biochemical Genetics, vol. 44, no. 11-12, pp. 479-482. http:// dx.doi.org/10.1007/s10528-006-9044-z. PMid:17109219.

FREIRE, C.M.M., MARQUES, M.O.M. and COSTA, M., 2006. Effects of seasonal variation on the central nervous system activity of Ocimum gratissimum L. essential oil. Journal of Ethnopharmacology, vol. 105, no. 1-2, pp. 161-166. http://dx.doi. org/10.1016/j.jep.2005.10.013. PMid:16303272.

GAZIM, Z.C., AMORIM, A.C.L., HOWELL, A.M.C., REZENDE, C.M., NASCIMENTO, I.A., FERREIRA, G.A. and CORTEZ, D.A.G., 2010. Seasonal variation, chemical composition, and analgesic and antimicrobial activities of the essential oil from leaves of Tetradenia riparia (Hochst.) codd in Southern Brazil. Molecules, vol. 15, no. 8, pp. 5509-5524. http://dx.doi.org/10.3390/ molecules15085509. PMid:20714310.

GOBBO-NETO, L. and LOPES, N.P., 2007. Plantas medicinais: fatores de influência no conteúdo de metabólitos secundários. Quimica Nova, vol. 30, no. 2, pp. 374-381. http://dx.doi.org/10.1590/ S0100-40422007000200026.

GONZÁLES-CHÁVEZ, M.M., CÁRDENAS-ORTEGA, N.C., MÉNDEZ-RAMOS, C.A. and PÉREZ-GUTIÉRREZ, S., 2011. Fungicidal properties of the essential oil of Hesperozygis marifolia on Aspergillus flavus link. Molecules, vol. 16, no. 3, pp. 2501-2506. http://dx.doi.org/10.3390/molecules16032501. PMid:21407150.

GRAUSGRUBER-GROGER, S., SCHMIDERER, C., STEINBORN, R. and NOVAK, J., 2012. Seasonal influence on gene expression of monoterpene synthases in Salvia officinalis (Lamiacae). Journal of Plant Physiology, vol. 169, no. 4, pp. 353-359. http://dx.doi. org/10.1016/j.jplph.2011.11.004. PMid:22196947.

HASHEMI, S.M., HOSSEINI, B. and ESTAJI, A., 2013. Chemical composition and insecticidal properties of the essential oil of Salvia leriifolia Benth (Lamiaceae) at two developmental stages. Journal of Essential Oil Bearing Plants, vol. 16, no. 6, pp. 806-816. http:// dx.doi.org/10.1080/0972060X.2013.854493.

HUSSAIN, A.I., ANWAR, F., CHATHA, S.A.S., LATIF, S., SHERAZI, S.T.H., AHMAD, A., WORTHINGTOM, J. and SARKER, S.D., 2013. Chemical composition and bioactivity studies of the essential oils from two Thymus species from the Pakistani flora. LWT - Food Science and Technology, vol. 50, no. 1 , pp. 185-192.

INSTITUTO BRASILEIRO DE GEOGRAFIA E ESTATÍSTICA - IBGE, 2014 [viewed 14 January 2014]. Descobrindo os biomas brasileiros [online]. Brasília. Available from: http://www.ibge.gov.br

KOC, S., OZ, E., CINBILGEL, I., AYDIN, L. and CETIN, H., 2013. Acaricidal activity of Origanum bilgeri P.H. Davis (Lamiaceae) essential oil and its major component, carvacrol against adults Rhipicephalus turanicus (Acari: Ixodidae). Veterinary Parasitology, vol. 193, no. 1-3, pp. 316-319. http://dx.doi.org/10.1016/j. vetpar.2012.11.010. PMid:23218220.

LAKUŠIĆ, B.S., RISTIC, M.S., SLAVKOVSKA, V.N., MILENKOVIC, M. and LAKUŠIĆ, D., 2011. Environmental and Seasonal impacts on the chemical composition of Satureja horvatii Silic (Lamiaceae) essential oils. Chemistry \& Biodiversity, vol. 8, no. 3, pp. 483-493. http://dx.doi.org/10.1002/cbdv.201000169. PMid:21404432.
LAKUŠIĆ, B.S., RISTIĆ, M.S., SLAVKOVSKA, V.N., STOJANOVIĆ, D.L. and LAKUŠIĆ, D.V., 2013. Variations in essential oil yields and compositions of Salvia officinalis (Lamiaceae) at different developmental stages. Botanica Serbica, vol. 37 , no. 2 , pp. 127-139.

LIMA, H.R.P., KAPLAN, M.A.C. and CRUZ, A.V.M., 2003. Influência dos fatores abióticos na produção e variabilidade de terpenóides em plantas. Floresta e Ambiente, vol. 10, no. 2, pp. 71-77.

LUKAS, B., SCHMIDERER, C. and NOVAK, J., 2013. Phytochemical diversity of Origanum vulgare L. subsp. vulgare (Lamiaceae) from Austria. Biochemical Systematics and Ecology, vol. 50, pp. 106-113. http://dx.doi.org/10.1016/j.bse.2013.03.037.

MARDIA, K.V., KENT, J.T. and BIBBY, J.M., 1994. Multivariate analysis. London: Academic Press, pp. 213-384.

MARTINI, M.G., BIZZO, H.R., MOREIRA, D.D.L., NEUFELD, P.M., MIRANDA, S.N., ALVIANO, C.S., ALVIANO, D.S. and LEITÃO, S.G., 2011. Chemical composition and antimicrobial activities of the essential oils from Ocimum selloi and Hesperozygis myrtoides. Natural Product Communications, vol. 6, no. 7, pp. 1027-1030. PMid:21834250.

MECHERGUI, K., COELHO, J.A., SERRA, M.C., LAMINE, S.B., BOUKHCHINA, S. and KHOUJA, M.L., 2010. Essential oils of Origanum vulgare L. subsp.glandulosum (Desf.) Ietswaart from Tunisia: chemical composition and antioxidant activity. Journal of the Science of Food and Agriculture, vol. 90, no. 10, pp. 1745-1749. http://dx.doi.org/10.1002/jsfa.4011. PMid:20564436.

MONFARED, A. and GHORBANLI, M., 2010. Composition of the essential oil of Salvia leriifolia Benth. growing wild in around of two mines in Iran. Research Journal of Phytochemistry, vol. 4, no. 1, pp. 13-17. http://dx.doi.org/10.3923/rjphyto.2010.13.17. PMid:19879608.

MORO, A., ZALACAIN, A., MENDOZA, J.H. and CARMONA, M., 2011. Effects of agronomic practices on volatile composition of Hyssopus officinalis L. essential oils. Molecules, vol. 16, no. 5, pp. 4131-4139. http://dx.doi.org/10.3390/molecules16054131.

MOSSI, A.J., PAULETTI, G.F., ROTA, L., ECHEVERRIGARAY, S., BARROS, I.B.I., OLIVEIRA, J.V., PAROUL, N. and CANSIAN, R.L., 2011. Effect of aluminum concentration on growth and secondary metabolites production in three chemotypes of Cunila galioides Benth. medicinal plant. Brazilian Journal of Biology = Revista Brasileira de Biologia, vol. 71, no. 4, pp. 1003-1009. http://dx.doi.org/10.1590/S1519-69842011000500020.

MOSSI, A.J., PAULETTI, G.F., ROTA, L., ECHEVERRIGARAY, S., BARROS, I.B.I., OLIVEIRA, J.V., PAROUL, N. and CANSIAN, R.L., 2012. Effect of different liming levels on the biomass production and essential oil extraction yield of Cunila galioides Benth. Brazilian Journal of Biology = Revista Brasileira de Biologia, vol. 72, no. 4, pp. 787-793. http://dx.doi.org/10.1590/ S1519-69842012000500002. PMid:23295505.

MUCCIARELLI, M., CAMUSSO, W., BERTEA, C.M. and MAFFEI, M., 2001. Effect of (+)- pulegone and other oil components of Mentha x piperita on cucumber respiration. Phytochemistry, vol. 57, no. 1, pp.91-98. http://dx.doi.org/10.1016/ S0031-9422(00)00393-9. PMid:11336266.

MUNÕZ-BERTOMEU, J., ARRILLAGA, I. and SEGURA, J., 2007. Essential oil variation within and among natural populations of Lavandula latifolia and its relation to their ecological areas. Biochemical Systematics and Ecology, vol. 35, no. 8, pp. 479-488. http://dx.doi.org/10.1016/j.bse.2007.03.006. 
NAJAFIAN, S., 2014. Storage conditions affect the essential oil composition of cultivated Balm Mint Herb (Lamiaceae) in Iran. Industrial Crops and Products, vol. 52, pp. 575-581. http://dx.doi. org/10.1016/j.indcrop.2013.11.015.

\section{NATIONAL INSTITUTE OF STANDARDS AND TECHNOLOGY} - NIST, 2010. NIST/EPA/NIH mass spectral library and search/ analysis programs. Hoboken: John Wiley \& Sons.

OZCAN, M.M., CHALCHAT, J.C., BAGCI, Y., DURAL, H., FIGUEREDO, G. and SAVRAN, A., 2011. Chemical composition of essential oils of Phlomis Grandiflora H.S. Thompson Var. Grandiflora flowers and leaves Of Turkish origin. Journal of Food Biochemistry, vol. 35, no. 1, pp. 125-132. http://dx.doi. org/10.1111/j.1745-4514.2010.00371.x.

PÉREZ-SÁNCHEZ, R., GÁLVEZ, C., UBERA, J.L., 2012. Bioclimatic influence on essential oil composition in South Iberian Peninsular populations of Thymus zygis. Journal of Essential Oil Research, vol. 24, no. 1, pp. 71-81

PIMENTEL, F.A., CARDOSO, M.G., ANDRADE, M.A., ZACARONI, L.M. and GUIMARÃES, L.G.L., 2012. Influência da secagem sobre o rendimento e composição química dos compostos voláteis das raízes de Piper piscatorum Trel. \& Yunck. (Piperaceae). Quimica Nova, vol. 35, no. 4, pp. 715-718. http:// dx.doi.org/10.1590/S0100-40422012000400011.

RAINA, A.P., KUMAR, A. and DUTTA, M., 2013. Chemical characterization of aroma compounds in essential oil isolated from "Holy Basil" (Ocimum tenuiflorum L.) grown in India. Genetic Resources and Crop Evolution, vol. 60, no. 5, pp. 1727-1735. http://dx.doi.org/10.1007/s10722-013-9981-4.

RIBEIRO, V.L.S., SANTOS, J.C., BORDIGNON, S.A.L., APEL, M.A., HENRIQUES, A.T. and VON POSER, G.L., 2010. Acaricidal properties of the essential oil from Hesperozygis ringens (Lamiaceae) on the cattle tick Rhipicephalus (Boophilus) microplus. Bioresource Technology, vol. 101, no. 1-3, pp. 2506-2509. http:// dx.doi.org/10.1016/j.biortech.2009.11.016. PMid:19954969.

ROESCH, L.F.W., VIEIRA, F.C.B., PEREIRA, V.A., SCHÜNEMANN, A.L., TEIXEIRA, I.F., SENNA, A.J.T. and STEFENON, V.M., 2009. The Brazilian Pampa: a fragile biome. Diversity, vol. 1, no. 2, pp. 182-198. http://dx.doi.org/10.3390/d1020182.

SAEI-DEHKORDI, S.S., TAJIK, H., MORADI, M. and KHALIGHI-SIGAROODI, F., 2010. Chemical composition of essential oils in Zataria multiflora Boiss. from different parts of Iran and their radical scavenging and antimicrobial activity. Food and Chemical Toxicology, vol. 48, no. 6, pp. 1562-1567. http:// dx.doi.org/10.1016/j.fet.2010.03.025. PMid:20332011.

SANDES, S.S., BLANK, A.F., BOTÂNICO, M.P., BLANK, M.F.A., VASCONCELOS, J.N.C. and MENDONÇA, S.A.D., 2012. Estruturas secretoras foliares em patchouli [Pogostemon cablin (Blanco) Benth.]. Scientia Plena, vol. 8, no. 5, pp. 1-6.

SANTOS, V.M.C.S., PINTO, M.A.S., BIZZO, H. and DESCHAMPS, C., 2012. Seasonal variation of vegetative growth, essential oil yield and composition of menthol mint genotypes at southern Brazil. Bioscience Journal, vol. 28, no. 5, pp. 790-798.

SELLAMI, I.H., REBEY, I.B., SRITI, J., RAHALI, F.Z., LIMAM, F. and MARZOUK, B., 2012. Drying sage (Salvia officinalis L.) plants and its effects on content, chemical composition, and radical scavenging activity of the essential oil. Food and Bioprocess Technology, vol. 5, no. 8, pp. 2978-2989. http://dx.doi. org/10.1007/s11947-011-0661-0
SILVA, D.T., SILVA, L.L., AMARAL, L.P., PINHEIRO, C.G., PIRES, M.M., SCHINDLER, B., GARLET, Q.I., BENOVIT, S.C., BALDISSEROTTO, B., LONGHI, S.J., KOTZIAN, C.B. and HEINZMANN, B.M., 2014. Larvicidal activity of brazilian plant essential oils against coenagrionidae larvae. Journal of Economic Entomology, vol. 107, no. 4, pp. 1713-1720. http:// dx.doi.org/10.1603/EC13361. PMid:25195467.

SILVA, J.C.S., HELDWEIN, A.B., MARTINS, F.B., TRENTIN, G. and GRIMM, E.L., 2007. Análise de distribuição de chuva para Santa Maria, RS. Revista Brasileira de Engenharia Agrícola e Ambiental, vol. 11, no. 1, pp. 67-72. http://dx.doi.org/10.1590/ S1415-43662007000100009.

SILVA, L.L., SILVA, D.T., GARLET, Q.I., CUNHA, M.A., MALLMANN, C.A., BALDISSEROTTO, B., LONGHI, S.J., PEREIRA, A.M.S. and HEINZMANN, B.M., 2013. Anesthetic activity of Brazilian native plants in silver catfish (Rhamdia quelen). Neotropical Ichthyology, vol. 11, no. 2, pp. 443-451. http://dx.doi.org/10.1590/S1679-62252013000200014.

TONI, C., BECKER, A.G., SIMÕES, L.N., PINHEIRO, C.G., SILVA, L.L, HEINZMANN, B.M., CARON, B.O. and BALDISSEROTTO, B., 2014. Fish anesthesia: effects of the essential oils of Hesperozygis ringens and Lippia alba on the biochemistry and physiology of silver catfish (Rhamdia quelen). Fish Physiology and Biochemistry, vol. 40, no. 3, pp. 701-714. PMid:24141557.

TOUATI, B., CHOGRANI, H., HASSEN, I., BOUSSAID, M., TOUMI, L. and BRAHIM, N.B., 2011. Chemical composition of the leaf and flower essential oils of Tunisian Lavandula dentata L. (Lamiaceae). Chemistry \& Biodiversity, vol. 8, no. 8, pp. 15601569. http://dx.doi.org/10.1002/cbdv.201000357.

TRINDADE, H., COSTA, M.M., SOFIA, B.L.A., PEDRO, L.G., FIGUEIREDO, A.C. and BARROSO, J.G., 2008. Genetic diversity and chemical polymorphism of Thymus caespititius from Pico, São Jorge and Terceira islands (Azores). Biochemical Systematics and Ecology, vol. 36, pp. 790-797. http://dx.doi.org/10.1016/j. bse.2008.09.001.

VENSKUTONIS, P.R., 1997. Effect of drying on the volatile constituents of thyme (Thymus vulgaris L.) and sage (Salvia oficinalis L.). Food Chemistry, vol. 59, no. 2, pp. 219-227. http:// dx.doi.org/10.1016/S0308-8146(96)00242-7.

VON POSER, G.L., MENUT, C., TOFFOLI, M.E., VÉRIN, P., SOBRAL, M., BESSIÉRE, J.M., LAMATY, G. and HENRIQUES, A., 1996. Essential oil composition and allelopathic effect of the Brazillian lamiaceae Hesperozygis ringens (BENTH.) Eplig and Hesperozygis rhododon Eplig. Journal of Agricultural and Food Chemistry, vol. 44, no. 7, pp. 1829-1832. http://dx.doi. org/10.1021/jf950653c.

YOUSEFZADEH, S., MODARRES-SANAVY, S.A.M., SEFIDKON, F., ASGARZADEH, A., GHALAVAND, A. and SADAT-ASILAN, K., 2013. Effects of Azocompost and urea on the herbage yield and contents and compositions of essential oils from two genotypes of dragonhead (Dracocephalum moldavica L.) in two regions of Iran. Food Chemistry, vol. 138, no. 2-3, pp. 1407-1413. http:// dx.doi.org/10.1016/j.foodchem.2012.11.070. PMid:23411261.

ZOUARI, N., FAKHFAKH, N., ZOUARI, S., BOUGATEF, A., KARRAY, A., NEFFATI, M. and AYADI, M.A., 2011. Chemical composition, angiotensin I- converting enzyme inhibitory, antioxidant and antimicrobial activities of essential oil of Tunisian Thymus algeriensis Boiss. et Reut. (Lamiaceae). Food and Bioproducts Processing, vol. 89, no. 4, pp. 257-265. http://dx.doi.org/10.1016/j. fbp.2010.11.006. 